\title{
The Use of Participatory Object-Oriented Bayesian Networks and Agro-Economic Models for Groundwater Management in Spain
}

\author{
Gema Carmona · Consuelo Varela-Ortega • \\ John Bromley
}

\begin{abstract}
This paper describes the development of a participatory decision support system for water management in the Upper Guadiana basin in central Spain where there has long been competition for groundwater resources between the agricultural sector and the environment. In the last few decades the rapid development of irrigation has led to the over-exploitation of the Mancha Occidental aquifer, the main water source in the area; this in turn has led to the loss of ecologically important wetlands. Against this background the River Basin Authority (RBA) has designed a new water management plan aimed at reducing water consumption. The objective of this paper is to evaluate the impact of these measures on both the environment and the agricultural sector. To this end stakeholders have been invited to actively participate in the development of a decision support system (DSS) based on the combination of an agro-economic model and an object-oriented Bayesian network. This DSS has been used to evaluate the trade-off between agriculture and the environment for different management options at different scales. Results indicate that achieving even a partial recovery of the aquifer water levels will require strict enforcement by the RBA of water restrictions on farmers combined with a high offer price for the purchase of water rights. However, compliance with water restrictions inevitably leads to losses in farm income, especially in small vineyard farms, unless additional measures are taken to compensate for those potential losses. The purchase of water rights alone is insufficient to ensure the recovery of water
\end{abstract}

G. Carmona (函) C. Varela-Ortega

Departamento Economía y CC.SS Agratias, Universidad Politécnica de Madrid.

ETSI Agrónomos, Madrid, Spain

e-mail: gema.carmona@upm.es

C. Varela-Ortega

e-mail: consuelo.varela@upm.es

J. Bromley

Water Management and Policy Group, Oxford Centre for Water Research, School of Geography and the Environment, University of Oxford, Oxford, UK e-mail: john.bromley@ouce.ox.ac.uk 
levels: accompanying measures included in the new regional management plan will also need to be undertaken.

Keywords Bayesian networks • Groundwater management •

Stakeholder participation • Decision support system

\section{Introduction}

\subsection{Participatory Decision Support Systems in IWRM}

Competition for water resources is at the root of many conflicts throughout the world: such conflict is expected to intensify as resources decline and demand increases in years to come (Jury and Vaux 2007). Being the most arid country in the European Union, water management is already one of the major socio-economic. environmental and institutional problems in Spain (Varela-Ortega 2010). Conflicts caused by competition for water are frequent in the region and agriculture, which is the main consumer of the resource, is a key component in the problem. Spain, like many arid and semiarid countries, has responded in the past few decades to the increase of water demand by encouraging intensive exploitation of the groundwater resource. This development has traditionally been undertaken by individual farmers, frequently in an uncontrolled manner, with minimum public involvement (Llamas and Martínez-Santos 2005). This has led to the over exploitation of aquifers, a situation that has been aggravated by a lack of coordination between water administrators and water users (Fornés et al. 2005).

In the face of many conflicting interests and the uncertainty surrounding the potential impacts of different strategies, water managers face the challenge of how best to manage the resource. Where agriculture is main water consumer, mathematical economic models have often been used to assess the impacts of scenarios or policies, using their capacity to link farmers' resource management decisions to current and alternative production possibilities (Cittadini et al. 2008: Janssen and van Ittersum 2007; Silva-Hidalgo et al. 2009). This type of model expresses the output of the farming systems in terms of economic results and environmental impacts of the farming activity and thus allows the ex-ante assessment of policies. They have been specifically used to simulate farmers' reactions to water policy scenarios and to analyse their impact on agricultural production, rural livelihoods and water resources (Alary and Deybe 2005: Gómez-Limón and Riesgo 2004).

However, an econonic model is not enough in complex situations, where different stakeholders with diverse interests can be affected by management decisions. In this context, a Decision Support System (DSS) that enables decision makers to simultaneously evaluate the impacts of optional strategies over a wide range of factors (economic, social and environmental) is required. Such a system benefits from the participation of stakeholders in its design, especially when dealing with complex issues: this is a move from a classical modelling approach to a more participative methodology (Costanza and Ruth 1998; Van Asselt-Marjolein and Rijkens-Klomp 2002: Vennix et al. 1996; Vennix 1999). The active involvement of all relevant stakeholder groups can additionally help to foster a sense of ownership of the decision making process (Gurung et al. 2006; Lynam et al. 2007). 
Participation is, moreover, one of the pillars of the "Integrated Water Resource Management" concept (Global Water Partnership 2000), which has been encouraged in the development of sustainable management agendas to help cope with the challenges posed by overexploited areas. In Europe, this concept has been supported by the Water Framework Directive (WFD), which represents a change in the way that water resource issues are handled (Pahl-Wostl et al. 2008). With this IWRM perspective, many authors recognise that participation needs to be an integral part of the construction of the decision making process (Sgobbi and Giupponi 2007).

Public participation is a requirement for IWRM and for many legal frameworks. but it needs an adequate implementation strategy. Models provide a scientifically based approach to predictions, but without the element of participation it is often difficult to transfer the results to policy making (Borowski and Hare 2007). Some examples of successful participatory DSSs that allow policy makers to compare different management strategies are reported in Mysiak et al. (2005). In other instances participatory decision tools allow the integration of knowledge obtained from formal methods (mathematical models) and from stakeholders and serve as a platform to organize the debate (Giordano et al. 2007: De Kok et al. 2009).

Participatory modelling makes problem solving more straightforward and improves mutual understanding between science, policymakers and stakeholders (Van Asselt-Marjolein and Rijkens-Klomp 2002: Winz et al. 2009). Some authors have emphasized the importance of participation in the particular case of environmental decision making (Antunes et al. 2006, Videira et al. 2009), highlighting the need to be able to evaluate alternatives if the participatory tool is to be useful for decision making. Potential tools include visualization software, conceptual methods. or quantitative methods (system dynamics) that facilitate problem structuring and group decision support. Another method able to structure participation and decision making makes use of Bayesian networks (BN). These are DSSs based on Bayes' probability theory, especially suited to the simulation of systems in which uncertainty is present due to imperfect or incomplete knowledge. They can be built with the participation of stakeholders, and have long been applied in fields such as medicine and artificial intelligence but only more recently in natural resources management (Cain 2001: Cain et al. 2003; Martín de Santa Olalla et al. 2005, 2007; Molina et al. 2009: Varis 1997). A key feature includes the ability to link different types of information (Bromley et al. 2005. Jensen 2001). But the main advantages of BNs over other tools are: (1) the graphical nature and visual simplicity of the technique, which facilitates interaction with stakeholders who have different backgrounds (Bacon et al. 2002. Batchelor and Cain 1999, Cain et al. 1999); (2) BNs explicitly take into account and openly represent uncertainty in decision making; and (3) they offer the opportunity to couple networks with other types of model. In this context, the option to link with economic models is particularly important.

\subsection{Case Study}

The Upper Guadiana basin covers an area of $18,900 \mathrm{~km}^{2}$, and is located in the central plateau of Spain (see Fig. 1).

The area experiences low and irregular precipitation. Groundwater is the major source of water supply, and agriculture is the main water user, accounting for $90-95 \%$ of total water consumption. However, the environmental demand is also 


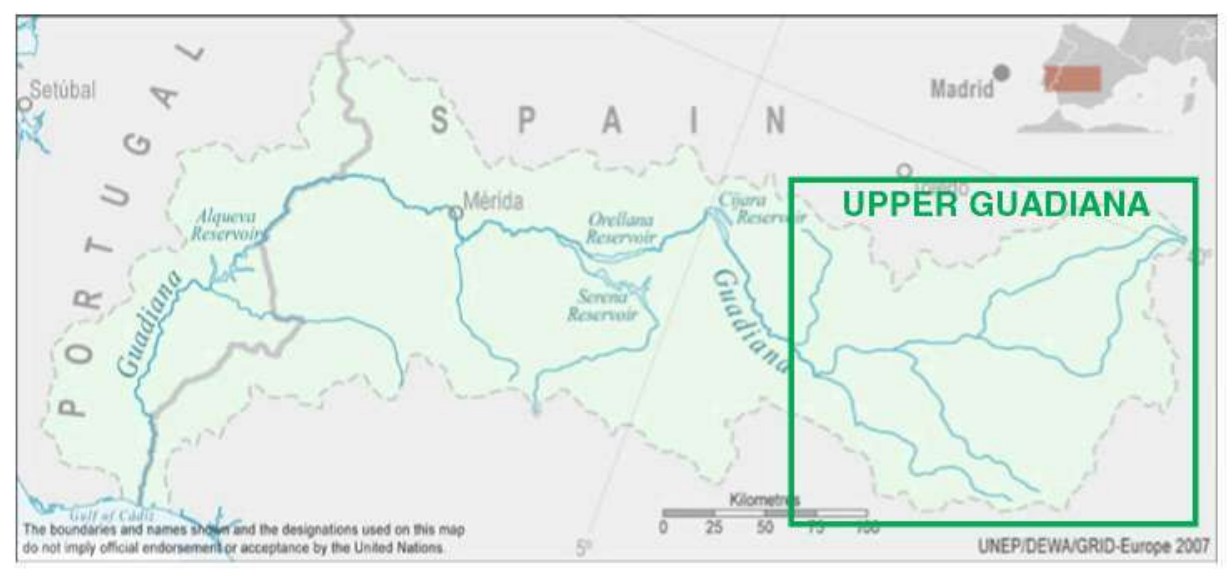

Fig. 1 Location of the Upper Guadiana basin. Source: modified from UNEP/DEWA/GRID-Europe 2007

crucial in the catchment, which contains wetlands declared as a Biosphere Reserve by UNESCO, and protected by the RAMSAR convention because of their rich biodiversity (De la Hera 2003).

Since the 1970s, irrigation has rapidly developed in response to several factors: new techniques which increased irrigation profitability and diminished drilling costs, national policies directed to irrigation development as a means of increasing wealth and population stability, and the Common Agricultural Policies (CAP) including coupled subsidies, which encouraged high added value (and high water demanding) crops (Varela-Ortega et al. 2003; Varela-Ortega 2007). Expansion of irrigation led to rapid economic development of the region but a marked decline of groundwater levels, leading to severe environmental damage (Rosell and Viladomiu 1997). The damage included the desiccation of water courses, disappearance of wetlands including the Mancha Húmeda Biosphere Reserve (UNESCO), deterioration of groundwater quality, and particularly noteworthy the damage of the RAMSARprotected Tablas de Daimiel wetlands (Coleto et al. 2003; Martínez-Cortina and Cruces 2005).

The National Water Law enacted in 1985 led to the declaration of the Mancha Occidental aquifer overexploitation in 1989 and the consequent implementation of annual Water Exploitation Plans limiting water abstraction to farmers, which has generated considerable social opposition and a general lack of compliance. The current situation is mired in uncertainty and confusion. There is conflict between stakeholder groups, a high but unknown number of illegal wells are scattered throughout the region and there is uncertainty regarding the real volume of groundwater abstracted from the aquifer. Among policies directed toward the reduction of groundwater abstractions, only the European Agri-Environmental Programmes, applied in the period 1993-1998, enjoyed any degree of success in raising the water table, but at a high cost to the public sector. At present, the decoupling of CAP subsidies and the cross-compliance requirements are leading to a trend towards lower water intensive crops (Garrido and Varela-Ortega 2008; Varela-Ortega 2007). In recent years, since the WFD came into effect, European legislation has served 
to reinforce national regulations and may ultimately lead to a reduced social cost (Varela-Ortega 2007).

In January 2008 (C.H.G. 2007a) a Special Plan for the Upper Guadiana basin (SPUG) was passed, with a 5.500 M€ budget. The aim was to help recover the levels and quality of groundwater bodies and improve the health of related ecosystems. while at the same time maintaining the viability of the local economy. The main feature of this plan is the purchase of water rights from farmers by the River Basin Authority. The purchase of water rights, together with a series of accompanying measures, is intended to reduce aquifer water abstraction from 624 to $200 \mathrm{Mm}^{3}$ year ${ }^{-1}$. Hopes of a definitive solution for water problems in the basin, rest with the SPUG.

\subsection{Objectives of the Research}

The objective of this research is to construct a decision support system (DSS) for groundwater management with the active involvement of stakeholders. This DSS is designed to identify sustainable socio-economic and environmental strategies for the Upper Guadiana region and to provide a platform for stakeholder participation for water management in the basin.

\section{Methodology}

\subsection{General Methodological Scheme}

The participatory DSS designed for water management decision making in the Upper Guadiana has two main components:

- An object-oriented Bayesian network. which represents the water management system and allows different management options to be tested.

- An agro-economic model, which reproduces farmers' behaviour when different policies are applied.

The first step in the economic analysis of the basin was the selection of a statistically based typology of farms in the area described in terms of size and crop type. Then, an agro-economic model was constructed at the farm level with the outputs from this model providing input to $\mathrm{BNs}$ also built at farm level. Individual networks representing each farm type were then aggregated into an object-oriented Bayesian network, which was used to assess the impacts of the whole system on the aquifer (see Fig. 2).

For the development of the DSS, we employed the stakeholder group selected during the NeWater project ${ }^{1}$ (representatives of the Irrigation Communities. Farmers' Associations, environmentalists, Guadiana River Basin Authority (RBA), Castilla la Mancha Agricultural Council, and other independent groups). Information from the group was obtained from a set of meetings held during the course of the NeWater project between 2005 and 2007 (Martínez-Santos et al. 2007).

\footnotetext{
${ }^{1}$ NeWater ("New Approaches to Adaptive Water Management under Uncertainty"), FP6-2003. GLOBAL-2-SUSTDEV-6.3.2-511179-2.
} 


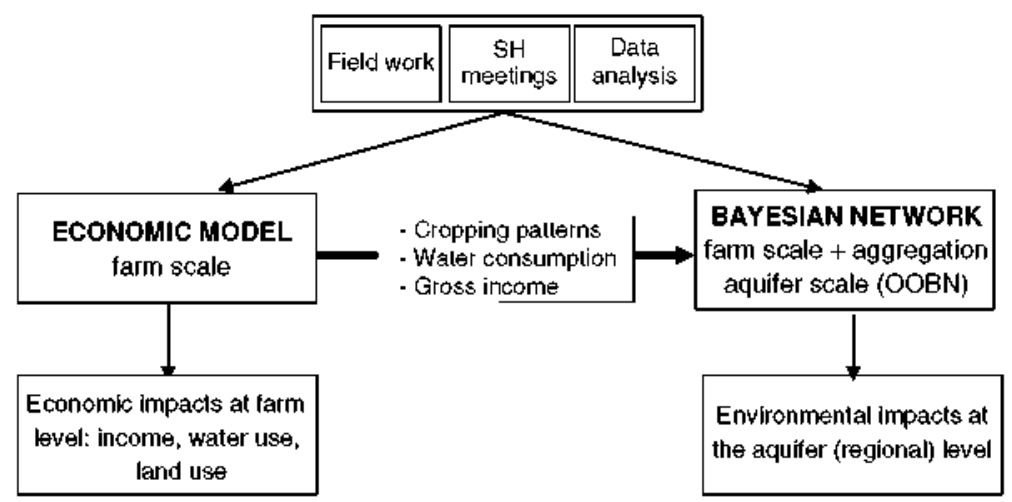

Fig. 2 Methodological scheme of the research

Following these meetings a participatory process was organized with the specific aim of developing the Bayesian networks, as shown in Table 1:

Stakeholders were thus involved throughout the DSS modelling process. The specific steps followed for the DSS development are explained in the following sections.

\subsection{Agro-Economic Models}

A non-linear mathematical programming model written in the General Algebraic Modeling System (GAMS) and built at the farm scale was constructed incorporating the previously defined farm typologies. The model represents farmers' behaviour by maximizing a utility function (U) subject to technical, economic and policy constraints (g), and including a risk component that takes into account the effect of climate (crop yields) and market uncertainties (crop prices). The utility function is defined by a gross margin (Z) and a risk vector (R) that includes climate as well as market price variability:

$$
\mathrm{U}=\mathrm{Z}-\mathrm{R}=\mathrm{Z}-\phi \cdot \sigma(Z)
$$

Table 1 Stakeholder meetings included in the participatory process for the development of the Bayesian networks in the Upper Guadiana basin

\begin{tabular}{|c|c|c|}
\hline Date & Format of meetings & Content \\
\hline \multirow{4}{*}{ May 2007} & 2 Group meetings: & Methodology explanation \\
\hline & $\begin{array}{l}\text { (1) Farmers + Agriculture Dept. } \\
\text { of Regional Government }\end{array}$ & Definition of variables \\
\hline & (2) Environmental $\mathrm{NGOs}+$ water & Development of preliminary network \\
\hline & Administration (River Basin Authority) & \\
\hline \multirow[t]{2}{*}{ January 2008} & Individual interviews & Definition of states of variables \\
\hline & & Definition of CPTs \\
\hline \multirow[t]{2}{*}{ February 2008} & Plenary meeting & Validation of the BN \\
\hline & & Completion of CPTs \\
\hline April 2008 & Plenary meeting & Validation of preliminary results \\
\hline November 2008 & Plenary meeting & Presentation of final results \\
\hline
\end{tabular}


where

$\mathrm{Z}=$ gross margin

$\phi=$ risk aversion coefficient

$\sigma(Z)=$ sum of standard deviations of the gross margin as a result of the variability of crop prices and yields

$\mathrm{U}$ is maximized subject a series of constraints $g(x) \in S_{1}, x \in S_{2}$, where "x" is the vector of the decision-making variables or vector of the activities defined by a given crop-growing area and by an associated production technique, irrigation method and soil type. The specific constraints taken into account in our model are as follows:

- Surface constraint: sum of surface per crop, technique and type of soil $\leq$ surface available in the farm. Irrigated surface and rain-fed surface are considered separately.

- Soil constraint: sum of surface per crop and technique for each type of soil $\leq$ maximum surface available in the farm for that type of soil

- Labour constraint: total labor needs per period = family labour available for the farm + hired labour in each period

- Water constraint: crop irrigation water needs $\leq$ water allotment assigned to the farm $\times$ water application technical coefficient.

- Policy constraints: maximum and minimum set-aside surface defined as a percentage of the CAP supported crops in both irrigated and rain-fed area.

The technical coefficients and parameters (crop prices, yields, prices of inputs. quantity of inputs for each crop and technique...) were obtained from fieldwork carried out in the area of study during 2007 and 2008. The model was calibrated using the risk aversion coefficient as a calibration parameter, then comparing it to historic data related to crop distribution, land and labour in the area.

Once calibrated, the economic model was used to evaluate the impact, in terms of economic results. water use and cropping patterns, of the joint application of several agricultural and water policies in the Upper Guadiana basin. Results were then used as input for the BNs.

\subsection{Bayesian Networks}

BNs are composed of a group of interrelated variables, linked in an acyclic structure. which define the system under study (Ames et al. 2005: Cain 2001; Jensen and Nielsen 2007). Each variable is characterized by the 'states' it can adopt, which can be defined as numeric values, intervals, qualitative estimations or Boolean functions. Next, relationships between the different variables are established in terms of probabilistic dependencies. For each variable, a conditional probability table (CPT) has to be defined, showing the probability distribution of that variable through its different states, given the states of its parent variables. The information about conditional probabilities can be obtained from various sources: direct measurements, mathematical models, or if no other data are available, expert opinion.

If we consider three nodes $\mathrm{A}, \mathrm{B}$ and $\mathrm{C}$, where $\mathrm{A}$ and $\mathrm{B}$ are conditionally independent, and $\mathrm{C}$ is conditionally dependent on $\mathrm{A}$ and $\mathrm{B}$, this would be represented as shown in Fig. 3. 
Fig. 3 Example of a simple $\mathrm{BN}$ formed by three variables $A, B$ and $C$

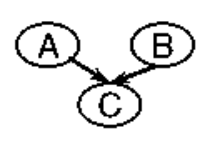

- Bayesian network formed by 3 nodes: A, B and C

- A, B independent, $C$ dependent on $A$ and $B$

- $A$ and $B$ are "parents" of C. ("child")

- Possible states of $A \rightarrow a_{1}, a_{2} ; B \rightarrow b_{1}, b_{2} ; C \rightarrow c_{1}: c_{2}$

If $\mathrm{A}, \mathrm{B}$ and $\mathrm{C}$ have two possible states each, then the $\mathrm{BN}$ model would require estimates of the marginal probabilities $\mathrm{P}\left(A=\mathrm{a}_{1}\right), \mathrm{P}\left(\mathrm{A}=\mathrm{a}_{2}\right), \mathrm{P}\left(\mathbf{B}=\mathrm{b}_{1}\right), \mathrm{P}(\mathrm{B}=$ $\mathrm{b}_{2}$ ) and the specification of the CPT representing the conditional probabilities for variable $\mathrm{C}$ :

$$
\begin{aligned}
& P\left(C=c_{1} / A=a_{1}, B=b_{1}\right), P\left(C=c_{1} / A=a_{1}, B=b_{2}\right), \\
& P\left(C=c_{1} / A=a_{2}, B=b_{1}\right), P\left(C=c_{1} / A=a_{2}, B=b_{2}\right), \\
& P\left(C=c_{2} / A=a_{1}, B=b_{1}\right), P\left(C=c_{2} / A=a_{1}, B=b_{2}\right), \\
& P\left(C=c_{2} / A=a_{2}, B=b_{1}\right), P\left(C=c_{2} / A=a_{2}, B=b_{2}\right) .
\end{aligned}
$$

When these probabilities are estimated, propagation of information through the $\mathrm{BN}$ is possible and can be used to assess the consequences of decisions or observed conditions ('evidence'). Once constructed, BNs can be used to identify the state of sub-groups of variables given the states of other variables on which the sub-group is dependant (parents), through the process called "probabilistic inference". The mathematical basis of this process is Bayes' Rule: $P(a 1, b 1 / c 1)=$ $\mathrm{P}(\mathrm{c} 1 / \mathrm{a} 1, \mathrm{~b} 1) \cdot \mathrm{P}(\mathrm{a} 1, \mathrm{~b} 1) / \mathrm{P}(\mathrm{c} 1)$

These calculations can be done using specialised commercial software such as Hugin Researcher (Hugin Expert A/S 2008).

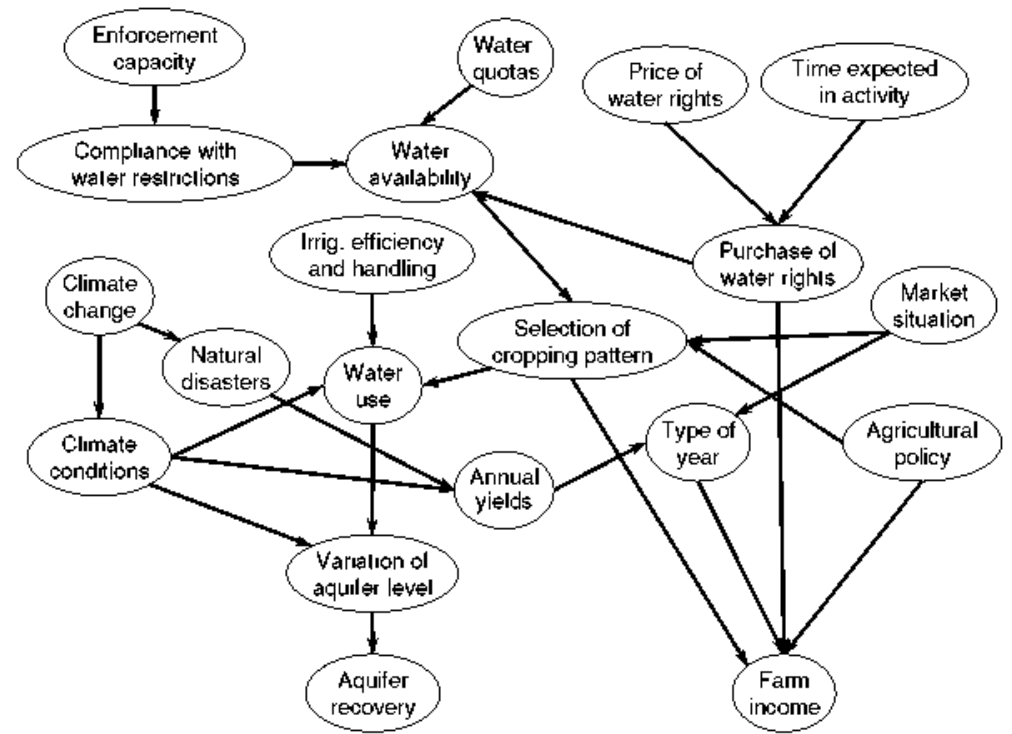

Fig. 4 Bayesian network representing the upper Guadiana system, focused on one farm type 

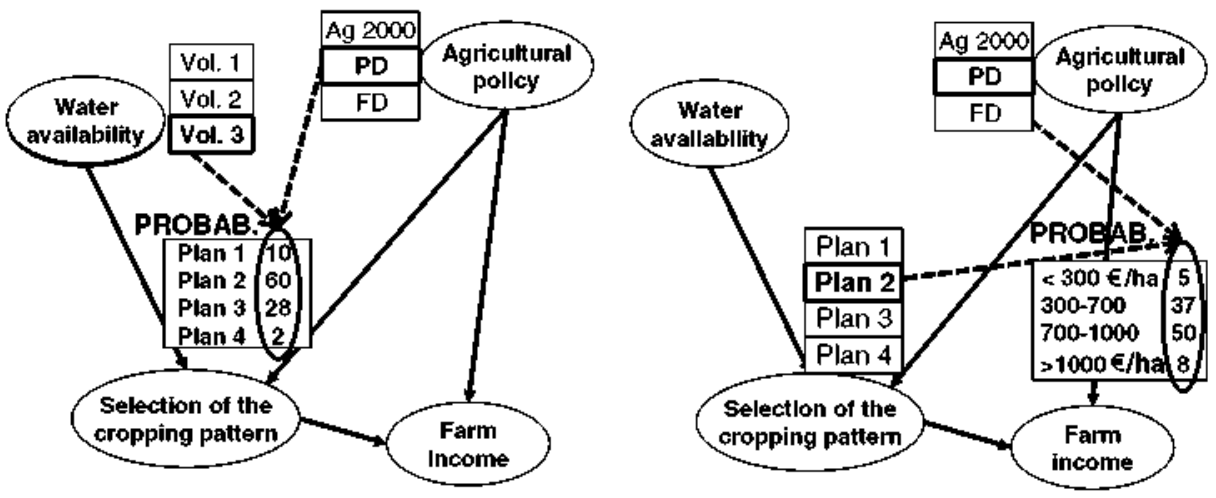

Fig. 5 Connection between economic model and Bayesian network

In our research, each type of farm is represented by a separate BN. All have the same structure but different values in the CPTs. The input for the CPTs was obtained from several sources: statistics and reports, stakeholder opinions, models, etc. The building process followed the guidelines set out in the EU project MERIT (Bromley 2005). Figure 4 shows the individual $B N$ corresponding to the farm scale.

The connection between the economic model and the $\mathrm{BN}$ is made through the relationship between the four following variables: water availability, agricultural policy, selection of the cropping pattern andfarm income. These relationships are established for each farm type and it is based on those specified in the economic model. Results from model simulations are used to fill some of the CPTs in the BN. as shown in Fig. 5.

The BNs developed at farm level are aggregated using an Object-Oriented network approach (Bangsø and Wuillemin 2000: Koller and Pfeffer 1997). Although there are no known examples of this type of construction in natural resources management, it has been chosen because it provides the opportunity to represent

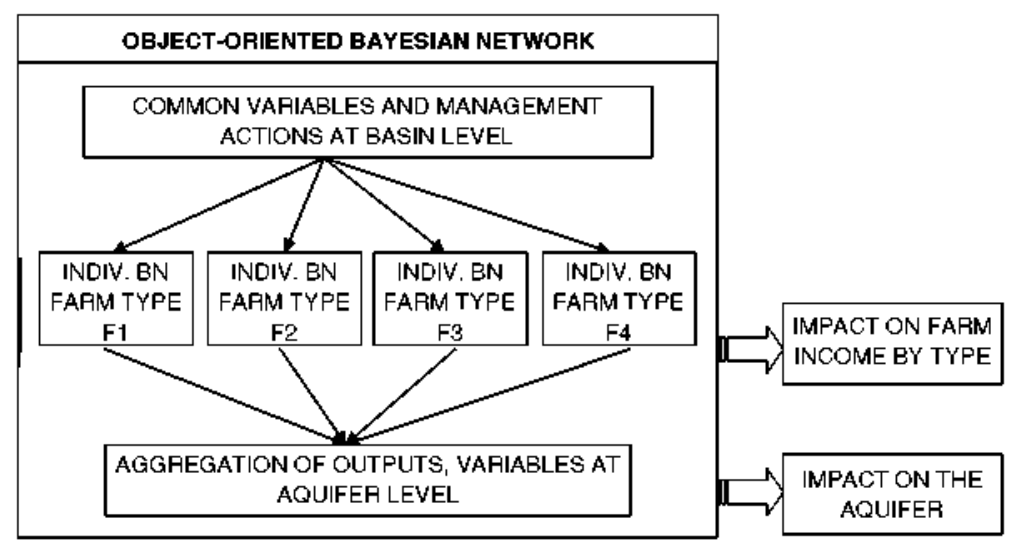

Fig. 6 Schematic representation of the aggregated, object-oriented Bayesian network of the Upper Guadiana basin 
repetitive structures in the same model and to analyse the system at different scales simultaneously. The aggregation process identifies common variables for all the farm types and uses them as inputs for each individual BN, and then aggregates some of the results in a joint output network, as shown in Fig. 6.

This structure enables the impact of different management actions on the economy of each farm type to be evaluated and, at the same time, the joint impact of all farm types on the aquifer. The advantage of the object oriented network in this case is to allow the simultaneous analysis of impacts at different scales, which is extremely useful in our context.

The overall process is not linear, but there must be feedback loops when new evidence appears during construction of the model.

\section{Simulation Scenarios}

When completed, the Bayesian network can be used to test different water management and climate scenarios to examine what happens to the two variables that have been selected as indicators of management performance namely, farm income and aquifer recovery. Scenarios are simulated by fixing the states of relevant input variables, which then generate a distribution of probabilities for the child variables selected as indicators. The object of the exercise is to evaluate the trade-off between water for food and water for nature, the two main elements in the competition for water resources in the case study. Simulations allow us to identify the way in which farm income and groundwater levels respond to changes in factors considered to be responsible for overexploitation in the region: the types of policy implemented and the degree of compliance of the farmers with those policies. Among the policies considered are those included in the regional water management plan (C.H.G. 2007a). The main policy tool in this regional plan is the purchase of water rights at different price levels by the RBA from irrigators: but there are also some complementary measures shown in Table 2.

With respect to the CAP, we have simulated the impact of partially decoupled subsidies, which is the policy currently being implemented. Simulations have been made using the Water Abstraction Plan for the current year (C.H.G. 2007b).

To simulate different scenarios the states of input variables have been fixed, and the response of output variables (aquifer recovery and farm income) noted. Different scenarios tend to give rise to opposite responses in the two main output variables; as income increases, so aquifer recovery declines. In this way the trade off between the two factors can easily be evaluated for different scenarios. It is important to note that fixed input variables are common for all farm types in the basin, that is, their

Table 2 Expected water savings through the implementation of accompanying measures with a direct effect on water consumption

\begin{tabular}{lcl}
\hline & Vol. recovered $\left(\mathrm{Mm}^{3}\right)$ & Surface affected (ha) \\
\hline Reforestation & 108.8 & 68,000 \\
Programme of agrarian measures & 50.0 & 10,000 \\
Planning and monitoring & 48.0 & - \\
Total accompanying measures & 158.8 & 78,000 \\
\hline
\end{tabular}


values are fixed in the master network within the Object Oriented Bayesian Network (OOBN) general structure, while for the output variables we have two cases:

- Farm income is specific to a farm type and is not aggregated, as we are interested in noting the differential impacts of scenarios for each type of farm. Results have to be checked for each "class" of the OOBN.

- On the contrary, the Aquifer recovery is a regional variable, and it is the result of the aggregated effect of the different types of farms. Consequently, results will be taken from the final aggregation in the OOBN.

In the simulations, the following variables have been selected as input variables:

(1) Policies implemented: purchase of water rights from farmers by the RBA. simulating several offer prices, and

(2) The enforcement capacity of the RBA to make farmers comply with water restrictions.

Finally, after the simulations, we separately calculated the effect of the accompanying measures included in the SPUG, in order to find out the final probability for the aquifer recovery.

\section{Results and Discussion}

The results of $\mathrm{BN}$ simulations are presented as probability distributions extracted from the output variables. In Table 3, two input variables. Enforcenent capacity and Offer price of water rights is shown. Each variable has two possible states: for example, Enforcement capacity has the states 'high capacity', and 'low capacity'. For each combination of states for these two variables the probability distribution for three output variables, \% purchase, Farm income, and Aquifer recovery is given. These distributions are shown as the likelihood (in percentage) of each variable being in any particular state. For example, when Enforcement capacity is in the 'Low capacity' state and Offer price of water rights is in the 'Low prices' state, then the

Table 3 Results of Bayesian network sinulations: \% purchase of water rights, distribution of farm income and probability of aquifer recovery as a result of the different levels of prices paid by the RBA for the water rights and different levels of the enforcement capacity of the RBA to make farmers comply with water restrictions

\begin{tabular}{|c|c|c|c|c|c|}
\hline & \multirow{2}{*}{$\begin{array}{l}\text { Enforcement capacity } \\
\text { Offer price of water rights }\end{array}$} & \multicolumn{2}{|c|}{ Low capacity } & \multicolumn{2}{|c|}{ High capacity } \\
\hline & & Low prices & High prices & Low prices & High prices \\
\hline \multirow[t]{2}{*}{$\%$ Purchase } & Yes & 5.4 & 50.9 & 29.8 & 68.9 \\
\hline & No & 94.6 & 49.1 & 70.2 & 31.1 \\
\hline \multirow{5}{*}{$\begin{array}{c}\text { Farm income } \\
\text { (average) }\end{array}$} & $<300$ & 5.9 & 4.8 & 6.2 & 4.0 \\
\hline & $300-500$ & 4.1 & 7.6 & 12.6 & 13.7 \\
\hline & $500-700$ & 12.9 & 9.3 & 19.4 & 12.1 \\
\hline & $700-900$ & 17.5 & 13.8 & 21.1 & 14.4 \\
\hline & $>900$ & 59.6 & 64.5 & 40.7 & 55.8 \\
\hline \multirow{3}{*}{$\begin{array}{l}\text { Aquifer } \\
\text { recovery }\end{array}$} & Before 2027 & 12.0 & 49.3 & 36.2 & 64.0 \\
\hline & Between 2027-2050 & 7.1 & 8.5 & 13.7 & 10.0 \\
\hline & Later/never & 80.9 & 42.2 & 50.1 & 26.0 \\
\hline
\end{tabular}


probability of the output variable \% Purchase being in its 'Yes' state is $5.4 \%$ and in the 'No' state $94.6 \%$.

Results show that the highest probability of attaining recovery of the aquifer level before 2027 is when the price paid for the water rights is high and the capacity of enforcement of the RBA is also high.

With respect to income for the average farm, the model shows reductions of between 5 and $10 \%$ when the enforcement capacity of the RBA is high, compared to the income with a low capacity of enforcement. However, variations in income distribution are not the same for all farm types, as shown in Fig. 7.

The results show that farm type F1 (small size, monoculture of vineyard) is the most affected by the increase of the enforcement capacity, while income for the larger farms is more affected by the price of water rights.

Table 4 shows the results for the aquifer recovery for the different levels of enforcement capacity of the RBA and offer prices for the purchase of water rights, when accompanying measures are applied to $75-100 \%$ of the expected level of implementation,.

Compared to results obtained with the application of the purchase of water rights alone, the probability of attaining the aquifer recovery is higher if accompanying
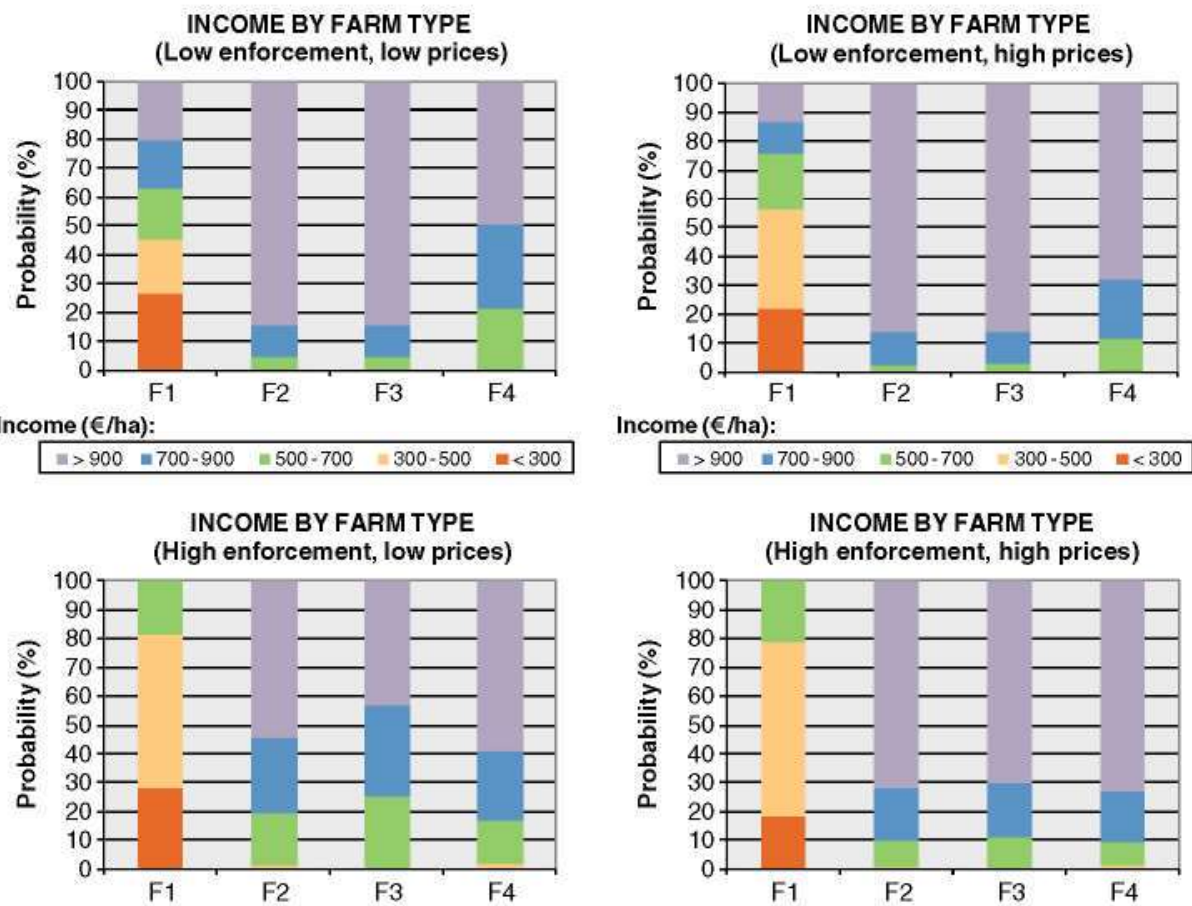

Income (€/ha):

$m>900=700-900 \quad \approx 500-700=300-500 \quad \approx<300$

INCOME BY FARM TYPE

(High enforcement, high prices)

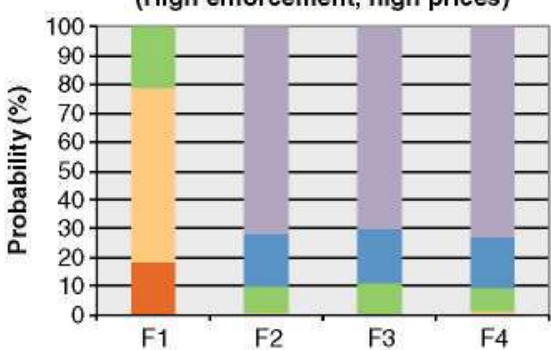

Income (€/ha):

$=>900=700-900 \quad \approx 500-700 \quad=300-500 \quad m<300$

Fig. 7 Income distribution per farm type, as a function of the capacity of enforcement of the RBA to make farmers comply with water restrictions and the prices paid by the RBA for the water rights. $F 1$ are small, vineyard farms; $F 2$ are medium-size farms with $100 \%$ annual crops; $F 3$ are medium-size farms with vineyard and $F 4$ are big farms 
Table 4 Probabilities to achieve the aquifer recovery when accompanying measures are attained in a $75-100 \%$ of expected

\begin{tabular}{llllll}
\hline Enforcement capacity & Low capacity & & & High capacity & \\
\cline { 2 - 3 } Offer price of water rights & Low prices & High prices & & Low prices & High prices \\
\hline Before 2027 & 20.1 & 58.5 & & 50.7 & 74.6 \\
Between 2027-2050 & 8.8 & 7.6 & & 11.4 & 7.8 \\
Later/never & 71.1 & 33.9 & & 37.9 & 17.7 \\
\hline
\end{tabular}

measures are also applied, increasing the probability of recovery before 2027 in about $10 \%$ for every combination Offer price of water rights-Capacity of enforcement and diminishing the probability of never recovering the aquifer level in approximately the same percentage (see Table 4 for comparison).

\section{Conclusions}

In a conflict situation where agriculture and nature compete for scarce water resources, the development of a DSS combining economic models and Bayesian networks have allowed the effects of water management decisions at different scales to be evaluated taking into account the impact on the agricultural system and the on the environment at a regional level.

Bayesian networks have been shown to meet the requirements of the water Framework Directive by: (1) Simultaneously being able to take into account all aspects of water use in the basin including the hydrological, socio-economic and environmental dimensions, (2) Being able to actively involve users and stakeholders in the decision making process, to increase public participation, and to foster social learning.

Object-oriented models have the additional advantage of being able to incorporate impacts at different scales. In our example it proved possible to evaluate the impact of each individual type of farm in isolation. but also on the joint effects of all types of farms at the regional level.

BN simulations have shown that the capacity of enforcement of the RBA to make farmers comply with water restrictions is a key element in water level recovery. It is not possible to achieve a reasonable probability for recovery of the aquifer if any one of two factors is missing: 1) high level of prices offered for the water rights, and 2) high capacity of enforcement of the RBA. In addition, the implementation of accompanying measures of the SPUG is necessary to achieve a high probability of recovery for the aquifer level, which cannot be achieved with the purchase of water rights alone.

The compliance with water restrictions inevitably leads to some loss in farm income, which is especially important for small vineyard farms. This could be avoided by additional measures to encourage quality production or improve marketing.

Acknowledgements The authors would like to acknowledge the European Commission, which has funded this research through the NeWater project ("New Approaches to Adaptive Water Management under Uncertainty"). FP6-2003-GLOBAL-2-SUSTDEV-6.3.2-511179-2. DG Research. European Commission) and the SCENES project ("Water Scenarios for Europe and for the Neighbouring States"), FP6-2005-GLOBAL-4(OJ 2005 C 177/15). A special acknowledgement is also due to the Spanish Ministry of Science and Technology, which has co-financed this research 
through the funds given for the project SEJ2005-25755-E: "Análisis de la gestión integrada del agua en la agricultura: efectos socio-económicos, ambientales e institucionales", complementary to NeWater.

\section{References}

Alary V, Deybe D (2005) Impacts of different water tariff reforms on rural livelihood and water and public resource in India: the case of Haryana producers. Int J Water 3:84-99

Ames DP, Neilson BT, Stevens DK, Lall U (2005) Using Bayesian networks to model watershed management decisions: an East Canyon Creek case study. J Hydroinform 7:267-282

Antunes P, Santos R, Videira N (2006) Participatory decision making for sustainable developmentthe use of mediated modelling techniques. Land Use Pol 23:44-52

Bacon PJ, Cain J, Howard DC (2002) Belief network models of land manager decisions and land use change. J Environ Manag 65:1-23

Bangs $\varnothing 0$, Wuillemin PH (2000) Top-down Construction and Repetitive Structures Representation in Bayesian Networks, Proceedings of the thirteenth international Florida artificial intelligence research society conference. The AAAI Press, Menlo Park. CA. 282-286

Batchelot C, Cain J (1909) Application of belief netwotks to water management studies. Agr Water Manag 40:51-57

Borowski I, Hare M (2007) Exploring the gap between water managers and researchers: difficulties of model-based tools to support practical water management. Water Resour Manag 21:10491074

Bromley J (2005) MERIT Project Guidelines. Guidelines for the use of Bayesian Networks as a participatory tool for Water Resources Management. A MERIT report. Centre for Ecology and Hydrology, Wallingford, UK, $118 \mathrm{pp}$

Bromley J, Jackson NA, Clymer OJ, Giacomello AM, Jensen FV (2005) The use of Hugin to develop Bayesian networks as an aid to integrated water resource planning. Environ Model Softw 20:231242

Cain J (2001) Planning improvements in natural resources management. Guidelines for using Bayesian networks to support the planning and management of development programmes in the water sector and beyond. Centre for Ecology and Hydrology, Wallingford, UK. $136 \mathrm{pp}$

Cain J, Batchelor C, Waughray D (1999) Belief networks: a framework for the participatory development of natural resource management strategies. Environ Dev Sustain 1:123-133

Cain J, Jinapala K, Makin IW, Somaratha BR, Ariyaratna BR, Perera LR (2003) Participatory decision support for agricultural management. A case study from Sri Lanka. Agr Syst 76:457482

C.H.G. (Confederación Hidrográfica del Guadiana) (2007a) Plan Especial Del Alto Guadiana. Documento De Síntesis. CHG, Ciudad Real, Spain

C.H.G. (Confederación Hidrográfica del Guadiana) (2007b) Régimen de explotación pata el año 2007 de la Unidad Hidrogeológica de la Mancha Occidental y de un perimetro adicional de la Unidad Hidrogeológica de la Sierra de Altomira. CHG, Ciudad Real, Spain

Cittadini ED, Lubbers MTMH, de Ridder N, van Keulen H, Claassen GDH (2008) Exploring options for farm-level strategic and tactical decision-making in fruit production systems of South Patagonia, Argentina. Agt Syst 98:189-198

Coleto C, Martínez-Cortina L, Llamas MR (2003) Conflictos Entre El Desarrollo De Las Aguas Subterráneas y La Conservación De Los Humedales: La Cuenca Alta Del Guadiana. Ediciones Mundi-Prensa, Madrid

Costanza R, Ruth M (1998) Using dynamic modeling to scope environmental problems and build consensus. Environ Manage 22:183-195

De Kok JL. Kofalk S, Berlekamp J, Hahn B. Wind H (2009) From design to application of a decisionsupport system for integrated river-basin management. Water Resour Manag 23(9):1781-1811

De la Hera A (2003) Caracterización de los bumedales de la cuenca alta del Guadiana. In: Coleto C, Martínez-Cortina L, Llamas MR (eds), Conflictos Entre El Desarrollo De Las Aguas Subterráneas y La Conservación De Los Humedales. Mundiprensa, Madrid, pp 165-196

Fornés JM. de la Hera A. Llamas MR (2005) The silent revolution in groundwater intensive use and its influence in Spain. Water Policy Not Known, pp 1-16

Garrido A, Varela-Ortega C (2008) Economía del agua en la agricultura y políticas sectoriales. Panel de Estudios. Universidad de Sevilla-Ministerio de Medioambiente 
Giordano R, Passarella G, Uricchio VF, Vurro M (2007) Integrating conflict analysis and consensus reaching in a decision support system for water resource management. J Environ Manag 84:213228

Global Water Partnership (2000) Integrated Water Resources Management. TAC Background Paper $N^{*}$ 4. Global Water Partnership, Stockholm, Sweden

Gómez-Limón JA, Rjesgo L (2004) Irrigation water pricing: differential impacts on irrigated farms. Agr Econ 31:47-66

Gurung TR, Bousquet F, Trébuil G (2006) Companion modeling, conflict resolution, and institution building: sharing irrigation water in the Lingmuteychu Watershed. Bhutan. Ecol $\mathrm{S} \propto \mathrm{c}$ 11:36

Hugin Expert A/S (2008) Hugin Researcher, version 6.9. User's Guide

Janssen S, van Ittersum MK (2007) Assessing farm innovations and responses to policies: a review of bio-economic farm models. Agr Syst 94:622-636

Jensen FV (2001) Bayesian networks and decision graphs. Springer, New York

Jensen FV, Nielsen TD (2007) Bayesian networks and decision graphs. Springer. New York

Jury WA, Vaux HJ (2007) The energing global water crisis: managing scarcity and conflict between water users. Adv Agron 95:1-76

Koller D. Pfeffer A (1997) Object-oriented Bayesian Networks. In: Proceedings of the thirteenth annual conference on uncertainty in artificial intelligence (AI-97). Rhode Island. USA, July 1997. pp 302-313

Llamas MR, Martínez-Santos P (2005) Intensive groundwater use: silent revolution and potential source of social conflicts. J Water Resour Plann Manag 131:337-341

Lynam T, de Jong W, Sheil D, Kusumanto T, Evans K (2007) A review of tools for incorporating community knowledge, preferences, and values into decision making in natural resources management. Ecol Soc 125

Martín de Santa Olalla FJ, Dominguez A, Artiago A. Fabeiro C, Ortega JF (2005) Integrated water resource management of the hydro-geological unit "Eastern Mancha" using Bayesian Belief networks. Agr Water Manag 77:21-36

Martín de Santa Olalla FJ, Domínguez Padilla A, Ottega F. Artiago Ramítez A, Fabeiro Cortes C (2007) Bayesian networks in planning a large aquifer in Eastern Mancha, Spain. Environ Model Softw 22(8):1089-1100

Martinez-Cortina L, Cruces J (2005) The analysis of the intensive use of groundwater in the Upper Guadiana Basin (Spain) using a numerical model. In: Sahuquillo A. Capilla J, Martínez-Cortina L, Sánchez-Vila X (eds) Groundwater Intensive use. Taylor \& Francis

Martínez-Santos P, Varela-Ortega C, Hernández-Mora N (2007) Making inroads towards adaptive water management through stakeholder involvement, the NeWater experience in the Upper Guadiana basin. Spain. International Conference of Adaptive and Integrated Water Management. Basel, Nov. 12-15

Molina JL, García-Aróstegui JL, Benavente JR, Varela-Ortega C, de la Hera A, López-Geta JA (2009) Aquifers overexploitation in SE Spain: a proposal for the integrated analysis of water management. Water Resour Manag 23(13):2737-2760

Mysiak J, Giupponi C, Rosato P (2005) Towards the development of a decision support system for water resource management. Environ Model Softw 20:203-214

Pahl-Wostl C, Kabat P, Möltgen J (2008) Adaptive and integrated water management-coping with complexity and uncertainty. Springer, Berlin

Rosell J, Viladomiu L (1907) El programa de compensación de rentas por reducción de regadios en Mancha Occidental y Campo de MontielAutores. Revista Española De Economía Agraria 179:331-350

Sgobbi A, Giupponi C (2007) Models and decision support systems for participatory decision making in integrated water resource management. In: Anonymous Options Méditerranéennes: Série B. Etudes et Recherches 56. CIHEAM-IAMB, Bari (Italy), pp 259-271

Silva-Hidalgo H, Martín-Domínguez IR, Alarcón-Herrera MT, Granados-Olivas A (2009) Mathematical modelling for the integrated management of water resources in hydrological basins. Water Resour Manag 23(4):721-730

Van Asselt-Marjolein BA. Rijkens-Klomp N (2002) A look in the mirtor: reflection on participation in integrated assessment from a methodological perspective. Glob Environ Change 12:167184

Varela-Ortega C (2007) Policy-driven determinants of irrigation development and environmental sustainability: a case study in Spain. In: Molle F. Berkoff $J$ (eds) Irrigation water pricing policy in context: exploring the gap between theory and practice. Comprehensive assessment of water management. IWMI and CABI press, pp 328-346 
Varela-Ortega C (2010) The water policies in Spain: balancing water for food and water for nature. In: Ingram H, Garrido A (eds) Water for food: quantity and quality in a changing world. Rosenberg International Forum on Water Policy. Routledge Publisher, Taylor and Francis Group, Abingdon

Varela-Ortega C, Sumpsi JM, Blanco M (2003) Análisis económico de los conflictos entre el regadío y la conservación de humedales en el Alto Guadiana. In: Coleto C. Martinez-Cortina L. Llamas MR (eds) Conflictos Entre El Desarrollo De Las Aguas Subterráneas y La Conservación De Los Humedales. Mundiprensa, Madrid, pp 257-276

Varis $O(1997)$ Bayesian decision analysis for environmental and resource management. Environ Softw 12:177

Vennix JAM (1999) Group model-building: tackling messy problems. Syst Dyn Rev 15:379-401

Vennix JAM, Andersen DF, Richardson GP, Rohrbaugh J (1996) Model building for group decision support: issues and alternatives in knowledge elicitation. In: Morecroft JDW. Sterman JD (eds), Modeling for learning organizations. Productivity Press, Inc.. Portland

Videira N, Antunes P, Santos R (2009) Scoping river basin management issues with participatory modelling: the Baixo Guadiana experience. Ecol Econ 68:965-978

Winz I, Brierley G, Trowsdale S (2009) The use of system dynamics simulation in water resources management. Water Resour Manag 23(7):1301-1323 